\title{
Quality of bottled waters in Turkey
}

\author{
Rustem Pehlivan \\ Istanbul University, Department of Geological Engineering, \\ 34320, Avcilar-Istanbul, Turkey \\ (Email: pehlivan@istanbul.edu.tr)
}

\begin{abstract}
In Turkey, 103 bottled waters (from natural springs and mineral waters) were sampled for testing their quality. The test revealed that in them some ions exceed the limits permitted by the World Health Organisation, European Community, and Turkish Standards. The appearance of $\mathrm{Fe}, \mathrm{Zn}, \mathrm{As}$, and $\mathrm{Al}$ in the natural spring and mineral waters indicates their inorganic contamination. Such bottled waters can cause adverse effects on human health. If the information reported on the bottled water consumed in Turkey and other countries of the world is updated with current results of water chemistry analysis, consumer's confidence in companies that produce them will increase.
\end{abstract}

\section{INTRODUCTION}

Water is one of life's essentials and makes up $60-70 \%$ of the human body. Consequently, humans must drink enough water to remain healthy. Bottled water containing toxic ions (heavy metals) can be detrimental to human health if consumed over long periods of time. During their movement, natural spring and mineral waters interact with the minerals constituting the aquifers and become contaminated.

Natural spring water is defined as the water that collects in aquifers and continuously flows naturally out of the ground at a specific point. Mineral water is defined as the water that collects at various depths under the earth's crust, contains dissolved minerals and carbon dioxide, emerges from the ground naturally, and has medicinal values. The spring water in question is bottled (Fig. 1) and distributed for drinking at local, regional, national, and international levels.

Because Turkey intends to become a member of the European Union in the near future (Fig. 2), it must evaluate the results of chemical analysis printed on the labels of bottled natural spring water and mineral water according to the limits recommended by the World Health Organisation (WHO), the European Commission (EC), and Turkish Standards (TS).

Various studies have been carried out in different countries of the world on the chemistry, water-rock interaction, and water quality of bottled spring water as well as mineral water used for drinking. Of these, Nkono and Asubiojo (1997) studied trace element contents of the Nigerian bottled water, Al-Salehu and Al-Doush (1998) studied the trace elements in the bottled drinking water and the municipal water of the city of Riyadh, van der Aa (2003) studied German mineral water and water standards, Reimann et al. (2003) studied the health and drinking water in Ethiopia, and Feru (2004) carried out research on bottled mineral water in Romania.

On the other hand, there have been a limited number of studies that have attempted to identify the status of consumer protection and the quality of bottled water (natural spring water and mineral water) used for drinking in Turkey. One of the first of these studies was carried out by Pehlivan and Yilmaz (1995) in which they reported the quality and potability of natural spring water and mineral water in the provinces of Istanbul, Sakarya, Bursa, and Canakkale. Pehlivan (1996) focused on the issues of drinking mineral waters. In more recent years, Pehlivan and Yilmaz (2005) researched on the water-rock interaction and water quality in the Buyukmelen River.

\section{TURKISH BOTTLED WATERS}

Establishing standards for quality and potability of bottled water consumed in Turkey that conform to the WHO, EU, and TS is necessary first of all for the Turkish people and secondly as part of the goal to join the European Union. To this aim, we will evaluate the water analysis results and the information on the labels of mineral water sold in 0.25 litre glass bottles and natural spring water sold in $0.25,0.5$, and 1.5 litre plastic bottles, and consumed all over Turkey as drinking water.

Consequently, a total of 103 bottles were purchased from neighbourhood stores, kiosks, and grocery stores in 2003 and 2005. The chemical analysis and information on the labels of these bottles were evaluated. Of the bottled water samples, 78 belonged to natural springs and 25 were mineral waters (Table 1 ). 


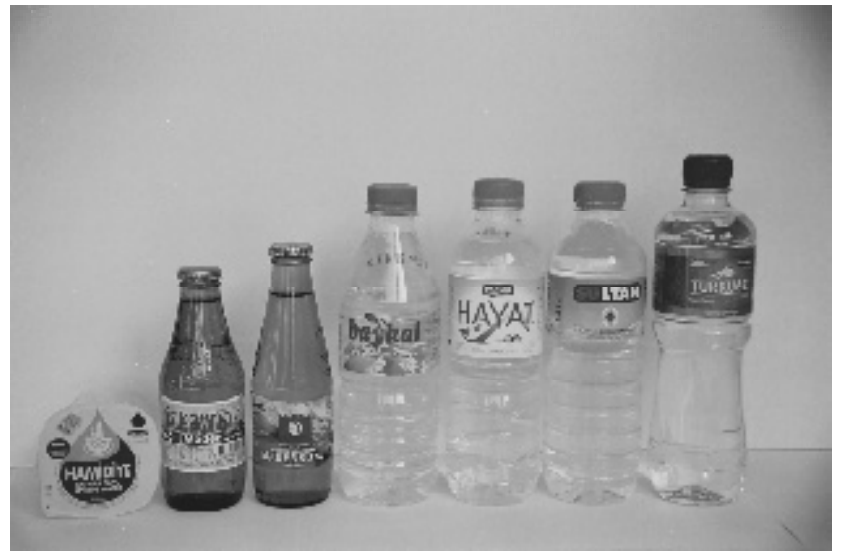

Fig. 1: The bottled waters in Turkey

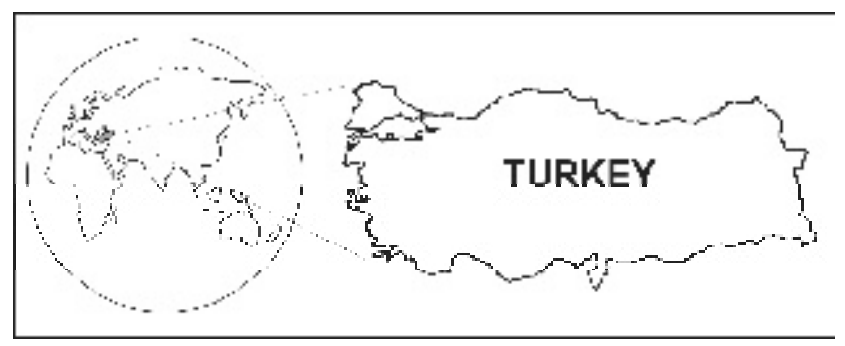

Fig. 2: Location map of Turkey

\section{CHEMISTRY OF NATURAL SPRINGAND MINERAL WATERS}

The amount of primary ions $\left(\mathrm{Na}^{+}, \mathrm{K}^{+}, \mathrm{Ca}^{2+}, \mathrm{Mg}^{2+}, \mathrm{SO}_{4}^{2-}\right.$, $\mathrm{HCO}_{3}^{-}$, and $\mathrm{Cl}^{-}$) in samples of natural spring or mineral waters is determined by the aquifer property and hydro-geochemical sources with which the springs interact. Hydro-geochemical origins were only identified for one sample (i.e. Kuzuluk mineral water) out of 103 samples gathered throughout Istanbul. The results of ion analysis of other bottled water brands were found to be incomplete (Table 2).

In locations where natural spring water and mineral water emerge from the ground, water quality can be enhanced by the existence of geological formations such as sand, gravel, limestone, marl, granite, and quartzite that do not negatively affect the chemistry of the water. If there is water-rock interaction in certain sedimentary, volcanic, and metamorphic rock or in fault zones, there may be an increase in the concentrations of certain heavy metals in spring water and mineral water in particular (Table 3).

As a result, in locations where certain natural and mineral springs emerge from the ground (such as in locations close to the provinces of Afyon, Duzce, Erzincan, Giresun, Manisa, Nevsehir, Tokat, Sakarya, and Samsun), the interaction of water with volcanic rock can cause springs to be enriched with elements such as Al, Fe, As, Ag, $\mathrm{Hg}, \mathrm{Co}, \mathrm{Cd}, \mathrm{Cr}, \mathrm{Pb}, \mathrm{Ni}$,
Table 1: The natural spring and mineral waters in Turkey

\begin{tabular}{|c|c|c|}
\hline Province & Natural spring water & Mineral water \\
\hline Adiyaman & Sersu & \\
\hline Afyon & Orucoglu, Kocapinar & Yildiz, Kizilay, Hisar \\
\hline Ankara & Saglik, Javsu & Kizilcahamam, Beypazari \\
\hline Antalya & Çaglarsu, Sural, Ceysu & \\
\hline Aydin & Pinar Madran, Topcam & \\
\hline Balikesir & Seker & Kristal \\
\hline Bolu & Anatolya & Akmina, Sodabant \\
\hline Burdur & Safir & Sifa \\
\hline Bursa & $\begin{array}{c}\text { Ozkaynak, Sultan, Sansu, Aroma, } \\
\text { Elmas, Turkuaz, Erikli, Baykal, } \\
\text { Korusu, Nestle }\end{array}$ & $\begin{array}{c}\text { Uludag, Ozkaynak, Sirma, } \\
\text { Cinar, Kinik, Diamaden }\end{array}$ \\
\hline Canakkale & Kizilcik & \\
\hline Corum & Cansu, Ozcamlik & \\
\hline Denizli & & Efe \\
\hline Duzce & Kabalak, Asya & \\
\hline Erzincan & & Bogert \\
\hline Erzurum & Palandoken & \\
\hline Eskisehir & Gecek, Tat & \\
\hline Giresun & Fatsu & Saricam, Inisdibi \\
\hline Isparta & Aysu, Ulusu, Denge & \\
\hline Istanbul & $\begin{array}{c}\text { Cobanpinar, Guvenpinar, Hisar, } \\
\text { Sirmakes, Mercan } \\
\text { Imren, Güzelpinar, Hamidiye, } \\
\text { Kumsu, Sadirvan } \\
\end{array}$ & \\
\hline Izmir & Pinar Sasal, Ozsu, Yamanlar & \\
\hline Kayseri & Pan & \\
\hline Kocaeli & Arksu, cenesuyu & \\
\hline Konya & Beysu, Ivriz & \\
\hline Manisa & Eges, Lidya & Sarikiz, Kula \\
\hline Mugla & Labranda, Sandras & Gokova \\
\hline Nigde & Tekir & \\
\hline Ordu & Cataltepe & \\
\hline Osmaniye & Esensu, Bahce & \\
\hline Sakarya & $\begin{array}{l}\text { Aytac, Saka, Sirma, Flora, } \\
\text { Serefiye, Hunkar, Kardelen, } \\
\text { Revan, Kristal, Hayat } \\
\end{array}$ & Kuzuluk \\
\hline Samsun & Emirhan & \\
\hline Tekirdag & & Ozgu \\
\hline Tokat & Niksar Ayvaz, Camlibel & \\
\hline Tunceli & Munzur & \\
\hline Van & Erek & \\
\hline Zonguldak & Selen & Yummy \\
\hline
\end{tabular}

$\mathrm{Ba}, \mathrm{Mn}, \mathrm{Zn}, \mathrm{Cu}, \mathrm{Se}, \mathrm{Sb}, \mathrm{B}$, and U (e.g. the Niksar Ayvaz spring water located in the volcanic rocks).

The fact that the quality of bottled water is sometimes at risk (i.e. some ions are above the limits) is closely related to the geological formations at the point of emergence, structural factors (particularly active faults), climate, and the mineralogy and geochemistry of the aquifer. Water chemistry can change significantly in instances where the spring is connected to a fault line (even after an earthquake), particularly for mineral water that is bottled and sold (for example, the Serefiye spring water, which is located in the North Anatolian Fault Zone).

The distribution of natural spring water and mineral water throughout Turkey that is consumed as drinking water (and 
Table 2: The chemical compositions of the bottled waters in Turkey (mg/l)

\begin{tabular}{|c|c|c|c|c|c|c|c|}
\hline & Topcam & Caglarsu & Cataltepe & Niksar Ayvaz & Serefiye & Kuzuluk & Hisar \\
\hline $\mathrm{pH}$ & 7,2 & 7,95 & 6,94 & 8 & 7,85 & $X$ & 7,2 \\
\hline $\mathrm{Na}$ & 3,3 & 1,53 & 4,97 & 3,4 & $\mathrm{X}$ & 1769,9 & 40,8 \\
\hline $\mathrm{K}$ & 1,9 & 0,31 & 4,06 & 5,7 & $X$ & 77 & $\mathrm{X}$ \\
\hline $\mathrm{Ca}$ & 6,6 & 38,47 & 9,62 & 1,2 & $X$ & 109,2 & $\mathrm{X}$ \\
\hline $\mathrm{Mg}$ & 3,4 & 15,8 & $\mathrm{X}$ & 0,4 & $X$ & 50,8 & $\mathrm{X}$ \\
\hline $\mathrm{Cl}$ & 8,5 & 8 & 10,3 & 8 & 0,037 & 759,7 & 26,3 \\
\hline $\mathrm{SO}_{4}$ & 3,0 & $\mathrm{X}$ & 0 & 4,2 & $\mathrm{X}$ & 55 & 18.2 \\
\hline $\mathrm{HCO}_{3}$ & $\mathrm{X}$ & $\mathrm{X}$ & $\mathrm{X}$ & $\mathrm{X}$ & $\mathrm{X}$ & 4026 & $\mathrm{X}$ \\
\hline $\mathrm{NO}_{3}$ & 6,6 & $\mathrm{X}$ & 14,64 & 1 & $\mathrm{X}$ & 0 & 0 \\
\hline $\bar{F}$ & 0,11 & 0,05 & 0,034 & 0,05 & 0,063 & $\mathrm{X}$ & 0,14 \\
\hline $\mathrm{Fe}$ & 0 & 0,01 & 0,034 & $\mathrm{X}$ & 4,9 & 4,5 & 20 \\
\hline $\mathrm{Zn}$ & 0,044 & 0,06 & 0,09 & $\mathrm{X}$ & $\mathrm{X}$ & $\mathrm{X}$ & $\bar{X}$ \\
\hline $\mathrm{Mn}$ & 0 & $\mathrm{X}$ & $\bar{X}$ & $\bar{X}$ & 0 & $\mathrm{X}$ & 0 \\
\hline $\mathrm{Al}$ & 0 & 0,01 & 0 & $\mathrm{X}$ & $\mathrm{X}$ & 2,5 & 0 \\
\hline $\mathrm{Cu}$ & 0 & 0,02 & $\mathrm{X}$ & $\bar{X}$ & $\mathrm{X}$ & $\mathrm{X}$ & $\mathrm{X}$ \\
\hline $\mathrm{Fe}+\mathrm{Al}$ & $\mathrm{X}$ & $\mathrm{X}$ & $\mathrm{X}$ & $\mathrm{X}$ & $\mathrm{X}$ & $\mathrm{X}$ & $\mathrm{X}$ \\
\hline $\mathrm{H}_{2} \mathrm{SiO}_{3}$ & $\mathrm{X}$ & $\mathrm{X}$ & $\mathrm{X}$ & $\mathrm{X}$ & $\mathrm{X}$ & 3,3 & $\bar{X}$ \\
\hline As & 0 & $\mathrm{X}$ & $\mathrm{X}$ & $0,118 *$ & $\mathrm{X}$ & $\mathrm{X}$ & $\mathrm{X}$ \\
\hline $\mathrm{Cd}$ & 0 & 0,001 & $\mathrm{X}$ & $\mathrm{X}$ & $\mathrm{X}$ & $\mathrm{X}$ & $\mathrm{X}$ \\
\hline $\mathrm{Cr}$ & $\mathrm{X}$ & 0,005 & $\mathrm{X}$ & $\mathrm{X}$ & $\bar{X}$ & $\mathrm{X}$ & $\mathrm{X}$ \\
\hline $\mathrm{Pb}$ & $\mathrm{X}$ & 0,0018 & $\mathrm{X}$ & $\mathrm{X}$ & $X$ & $\mathrm{X}$ & $\mathrm{X}$ \\
\hline $\mathrm{Cn}$ & $X$ & 0,001 & 0,001 & $\mathrm{X}$ & $\mathrm{X}$ & $X$ & $\mathrm{X}$ \\
\hline $\mathrm{Sb}$ & $\bar{X}$ & $\mathrm{X}$ & 0,001 & $\bar{X}$ & $\bar{X}$ & $\mathrm{X}$ & $\bar{X}$ \\
\hline Discharge location & Aydin & Antalya & Ordu & Tokat & Sakarya & Sakarya & Istanbul \\
\hline Analysis date & 27.4 .1999 & 02.2 .1999 & 21.05 .1976 & 31.12 .1975 & 23.5 .1984 & 29.7 .1976 & 04.8 .1997 \\
\hline
\end{tabular}

X: Data not available, * Analysis result of the Ministry of Health (June 01, 2002), 0,02 The highest level of a contaminant in drinking water

Table 3: Dominant lithology of the natural spring and mineral waters

\begin{tabular}{c|c|c}
\hline & Natural spring water & Mineral water \\
\hline $\begin{array}{c}\text { Sedimentary } \\
\text { rocks }\end{array}$ & Caglarsu, Hisar & \\
\hline $\begin{array}{c}\text { Metamorphic } \\
\text { rocks }\end{array}$ & $\begin{array}{c}\text { Topcam, Pinar Madran, } \\
\text { Baykal, Erikli, Çamlibel } \\
\text { Bursa Korusu, Elmas }\end{array}$ & Diamaden \\
\hline \multirow{4}{*}{ Volcanic rocks } & Orucoglu, Kocatepe, & Kizilcahamam, \\
& Gecek, Saglik, Emirhan, & Kuzuluk \\
& Palandoken, Beysu, \\
& Kizilcahamam, Kizilcik, & Saricam, \\
& Inisdibi \\
\hline \multirow{2}{*}{ Faults } & Aysu, Sersu, Serefiye, Erek & Sarikiz, Sifa, \\
& Bogert \\
\hline
\end{tabular}

which is mostly found in parts of western Turkey) is shown in Fig. 3 together with geological formations and structural factors at the point of emergence.

\section{QUALITY OF TURKISH BOTTLED WATERS}

The contamination of surface and groundwater is caused partly by geological formations but more significantly by domestic and industrial liquid waste. The bottled water that contains toxic ions (heavy metals) can be detrimental to human health if used for drinking over long periods of time (EPA 2001). Natural water is rarely polluted by physical and chemical decomposition that develops in the surrounding rock formations, but is more often polluted by ground pollution and industrial liquid wastes.

The study revealed that most of Turkish bottled water in question came from the provinces of Bursa, Istanbul, and Adapazari, that the bottled water analysis had not been updated, that the parameters measured were varied and that the time between the production date and the expiration date varied from 6 to 18 months. The chemical analysis results on the labels of some of the 103 bottles of water contained ions that were at the limit or above acceptable values set by the WHO (1993), EC, TS (TS 266 and TS 9130), and their regulations (Table 4).

Information on the bottled water labels showed that for some of the 103 bottles of water, the results of the bottled water analysis were obtained at the time the business obtained a license for operation. The chemical analyses of some of the bottles of water were even found to pose a risk to human health when compared with limits set by current standards and regulations. It is possible that public health was negatively affected during the dates in which the bottled water in question was sold for consumption. It is an incorrect practice to use the past label information on bottles without updating their current status of water quality. Sale of Niksar 


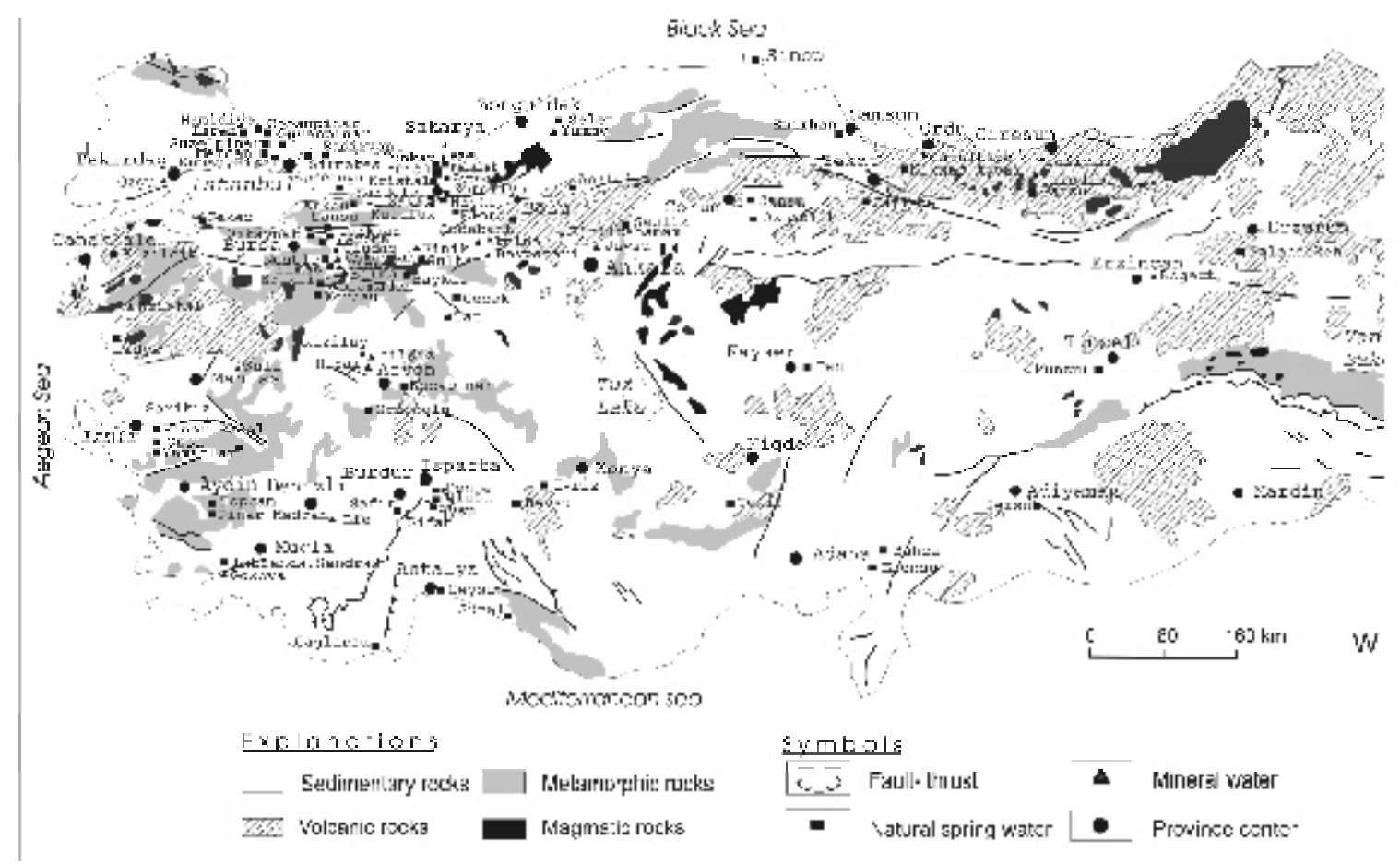

Fig. 3: Location map of the natural spring and mineral waters with the distribution of volcanic, metamorphic, magmatic and sedimentary rocks in Turkey

Ayvaz bottled water, which was produced in Turkey for many years and exported to other countries, was stopped in 2002 and bottled water was recalled from the market by the Ministry of Health due to an increase in the concentration of As in the natural spring water.

\section{BOTTLED WATER IN CERTAIN EUROPEAN COUNTRIES}

The analysis of primary ions in bottled water produced in many parts of the world and exported to other countries was found to be complete. However the analysis of heavy metals was found to be incomplete (Table 5).

\section{HUMAN HEALTH}

In order for water bottled in Turkey to be put on the domestic market for retail sale, the labels on the bottled water must provide a place for information that describes the product. This requirement was put in place by Consumer Protection Act 4822. In order to comply with this act, producers are required to carry out the terms of directives issued by the Ministries of Health, Environment, Industry and Commerce (such as RG 25657, RG 23172, RG 25137 and $\mathrm{RG} 24473$ ). There is no provision for the information on the bottle labels to be renewed every year.

Results of water analysis carried out at the time when the license was obtained for the bottled water is indicated on the label, but this information is not updated in subsequent years. Consumers would like the water they drink to be of good quality and for it to have a positive effect on their health. Awareness on the importance of preserving human health and protecting consumers is spreading rapidly in Turkey as well as in Europe.

Humans consume natural spring water as drinking water and they drink mineral water to aid in digestion. If these waters contain ions that are at or above standard limits (WHO, EU, and TS), people that drink such water run a higher risk of catching a disease than those that drink healthy water. $\mathrm{Pb}$ in drinking water can potentially cause brain and kidney disorders, Mn can cause liver and nerve disorders, As can cause skin and stomach disorders, $\mathrm{Cd}, \mathrm{Cu}$, and $\mathrm{Hg}$ can cause kidney disorders, $\mathrm{Cr}$ can cause skin disorders, $\mathrm{NO}_{3}$ can cause skin and respiratory disorders (EPA 2001).

\section{RESULTS AND RECOMMENDATIONS}

In Turkey, even though companies that produce bottled water obtain their permission to operate from the Ministry of Health, the analysis results of 103 bottles of water were found to be incomplete and the information on the labels was generally out of date (Table 2). This situation was also found to be true for mineral water produced outside of Turkey and exported to other countries (Table 5).

Bottled water in Certain European Countries, such as San Pellegrino spring water, are sold in grocery stores in 
Table 4: The limits permitted by the World Health Organisation (WHO 1993), Turkish Standards (TS266, TS9130), European Community (80/777/EEC, 98/83/EC, 2003/40/EC) and Turkish Regulations (RG 24473 ve RG 25657) for mineral and drinking waters (mg/l)

\begin{tabular}{|c|c|c|c|c|c|c|c|c|c|}
\hline Ions & $\begin{array}{c}\text { Drinking } \\
\text { (WHO) }\end{array}$ & $\begin{array}{r}\text { Drinking } \\
\text { (TS 266) }\end{array}$ & $\begin{array}{c}\text { Drinking } \\
\text { (RG } \\
\text { 24473) }\end{array}$ & $\begin{array}{c}\text { Natural } \\
\text { spring } \\
\text { (TS 266) }\end{array}$ & $\begin{array}{c}\text { Natural } \\
\text { spring } \\
\text { (RG 24473) } \\
\end{array}$ & $\begin{array}{c}\text { Mineral } \\
\text { water } \\
\text { (TS 9130) }\end{array}$ & $\begin{array}{c}\text { Mineral } \\
\text { water } \\
\text { (RG 25657) } \\
\end{array}$ & $\begin{array}{c}\text { Mineral } \\
\text { water* }\end{array}$ & $\begin{array}{c}\text { Drinkin } \\
+\end{array}$ \\
\hline $\mathrm{pH}$ & $6.5-8.5$ & $6.5-9.2$ & $5.5-8.5$ & $6.5-8.5$ & $6.0-8.0$ & $X$ & $X$ & $X$ & $6.5-9.0$ \\
\hline $\mathrm{Cr}$ & 0.05 & 0.05 & 0.05 & 0.05 & 0.05 & 0.05 & 0.05 & 0.05 & 0.05 \\
\hline As & 0.01 & 0.05 & 0.01 & 0.05 & 0.01 & 0.05 & 0.01 & 0.01 & 0.01 \\
\hline $\mathrm{Se}$ & 0.01 & 0.01 & 0.01 & 0.01 & 0.01 & 0.01 & 0.01 & 0.10 & 0,01 \\
\hline $\mathrm{Ag}$ & 0.05 & 0.01 & $X$ & 0.01 & $X$ & $\mathrm{X}$ & $X$ & $X$ & $X$ \\
\hline $\mathrm{Sb}$ & 0.003 & 0.01 & 0.005 & 0.01 & 0.005 & 0.01 & 0.005 & 0.005 & 0.005 \\
\hline $\mathrm{Hg}$ & 0.001 & 0.001 & 0.001 & 0.001 & 0.001 & 0.001 & 0.001 & 0.001 & 0.001 \\
\hline $\mathrm{Fe}$ & 0.5 & 0.2 & 0.3 & 0.05 & 0.05 & $X$ & $X$ & 1.0 & 0.2 \\
\hline $\mathrm{Ni}$ & 0.02 & 0.05 & 0.02 & 0.05 & 0.02 & 0.05 & 0.02 & 0.02 & 0.02 \\
\hline $\mathrm{Na}$ & 200 & 175 & 175 & 20 & 30 & $X$ & $X$ & 200 & 200 \\
\hline $\mathrm{K}$ & $\mathrm{X}$ & 12 & 12 & 12 & 10 & $\mathrm{X}$ & $X$ & $\mathrm{X}$ & $\mathrm{X}$ \\
\hline $\mathrm{Ca}$ & $X$ & 200 & 100 & 100 & 100 & $\mathrm{X}$ & $X$ & 150 & $\mathrm{X}$ \\
\hline $\mathrm{Mg}$ & $X$ & 50 & 50 & 30 & 30 & $\mathrm{X}$ & $\mathrm{X}$ & 50 & $X$ \\
\hline $\mathrm{Ba}$ & 0.7 & 0.3 & $X$ & 0.1 & $X$ & 1.0 & 1.0 & 1.0 & $\mathrm{X}$ \\
\hline $\mathrm{B}$ & 0.5 & 2.0 & 0.3 & 1.0 & 1.0 & 6.0 & $X$ & $X$ & 1.0 \\
\hline $\mathrm{U}$ & 0.002 & $\mathrm{X}$ & $X$ & $X$ & $\mathrm{X}$ & $\mathrm{X}$ & $X$ & $X$ & $\mathrm{X}$ \\
\hline $\mathrm{Cl}$ & 250 & 600 & 250 & 30 & $X$ & $X$ & $X$ & $X$ & 250 \\
\hline $\mathrm{F}$ & 1.5 & 1.5 & 1.5 & 1.0 & 1.5 & 1.5 & 5.0 & 1.0 & 1.5 \\
\hline $\mathrm{SO}_{4}$ & 500 & 250 & 250 & 25 & 40 & $\mathrm{X}$ & $\mathrm{X}$ & 200 & 250 \\
\hline $\mathrm{NO}_{3}$ & 50 & 50 & 45 & 25 & 25 & 25 & 50 & 50 & 50 \\
\hline
\end{tabular}

X: Data not available, * Council Directive (80/777/EEC) and Commission Directive (2003/40/EC), + Council Directive (98/83/EC)

Table 5: The chemical compositions of the bottled waters in certain European Countries (mg/l)

\begin{tabular}{|c|c|c|c|c|c|c|c|c|c|}
\hline & $\begin{array}{c}\text { Romerquelle } \\
\text { (Avustria) }\end{array}$ & $\begin{array}{c}\text { Buxton } \\
\text { (England) }\end{array}$ & $\begin{array}{c}\text { Pioule } \\
\text { (France) }\end{array}$ & $\begin{array}{c}\text { Korpi } \\
\text { (Greece) }\end{array}$ & $\begin{array}{l}\text { Gerolsteiner } \\
\text { (Germany) }\end{array}$ & $\begin{array}{c}\text { Vivien } \\
\text { (Hungary) }\end{array}$ & $\begin{array}{c}\text { San Pellegrino } \\
\text { (Italy) }\end{array}$ & $\begin{array}{c}\text { Dea } \\
\text { (Poland) }\end{array}$ & $\begin{array}{c}\text { Sierra Cazorla } \\
\text { (Spain) }\end{array}$ \\
\hline $\mathrm{pH}$ & $\mathrm{X}$ & 7,4 & 7,3 & 7,3 & $\mathrm{X}$ & 7,2 & $X$ & 7,9 & 7,2 \\
\hline $\mathrm{Na}$ & 13,9 & 24 & 33,5 & 4,7 & 118 & 4 & 35,0 & 6 & 1,9 \\
\hline$\overline{\mathrm{Ca}}$ & 146,4 & 55 & 140,8 & 101,2 & 348 & 69 & 185,6 & 65,73 & 74,0 \\
\hline $\mathrm{Mg}$ & 65,6 & 19 & 11,4 & 2,1 & 108 & 51 & 52,5 & 9,72 & 40,2 \\
\hline $\mathrm{HCO}_{3}$ & 421 & 248 & 351 & 305,5 & 1816 & 464 & 237,9 & 226 & 386,7 \\
\hline $\mathrm{NO}_{3}$ & 0,5 & $<0,1$ & $\mathrm{X}$ & 4,3 & 1,5 & 3,7 & 2,0 & $X$ & $\mathrm{X}$ \\
\hline $\mathrm{F}$ & 0,5 & $\mathrm{X}$ & $\mathrm{X}$ & $X$ & $\mathrm{X}$ & 0,13 & $\mathrm{X}$ & 0,3 & $X$ \\
\hline I & $<0,01$ & $\mathrm{X}$ & $\mathrm{X}$ & $\mathrm{X}$ & $\mathrm{X}$ & $<0,01$ & $\mathrm{X}$ & $\mathrm{X}$ & $\mathrm{X}$ \\
\hline $\mathrm{Fe}$ & $<0,010$ & 0 & $\bar{X}$ & $\mathrm{X}$ & $\mathrm{X}$ & 0,06 & $\mathrm{X}$ & 0,3 & $\mathrm{X}$ \\
\hline $\mathrm{SiO}_{2}$ & $\mathrm{X}$ & $\mathrm{X}$ & 37 & $\mathrm{X}$ & $\mathrm{X}$ & $\mathrm{X}$ & 7,9 & $\mathrm{X}$ & $\mathrm{X}$ \\
\hline $\mathrm{Li}$ & $\mathrm{X}$ & $\mathrm{X}$ & $\mathrm{X}$ & $X$ & $X$ & 0,1 & $\bar{X}$ & $\bar{X}$ & $\mathrm{X}$ \\
\hline $\mathrm{Sr}$ & $\mathrm{X}$ & $\mathrm{X}$ & $\mathrm{X}$ & $\mathrm{X}$ & $\mathrm{X}$ & 620 & 2,7 & 340,34 & $\mathrm{X}$ \\
\hline $\mathrm{Si}$ & $\mathrm{X}$ & $\mathrm{X}$ & $\mathrm{X}$ & $\mathrm{X}$ & $\mathrm{X}$ & $\mathrm{X}$ & $\mathrm{X}$ & $\mathrm{X}$ & 3,8 \\
\hline TDS & $X$ & 280 & 647 & $\mathrm{X}$ & $\mathrm{X}$ & $\mathrm{X}$ & 952 & $X$ & 380 \\
\hline Analysis date & $\mathrm{X}$ & $\mathrm{X}$ & $\mathrm{X}$ & 27.01 .1998 & 23.04 .1986 & 2000 & $\mathrm{X}$ & $\mathrm{X}$ & 1997 \\
\hline
\end{tabular}

X: Data not available 


\section{Rustem Pehlivan}

Turkey. In addition, some brands of natural spring water and mineral water produced in Turkey are exported to other countries (for example, Saka bottled water).

Chemical compounds contained in surface and underground water vary due to interaction with geological formations and due to physical and chemical decomposition of the surrounding rock formations. This change can increase the concentration of certain ions in natural water. Natural water can contain certain heavy metals that can be detrimental to human health.

These heavy metal contents in the bottled waters are related to geological origin. Further, some studies should be carried out for detailed water-rock interaction especially on the mineral water in fault systems (i.e. Kuzuluk, Sarikiz, Sifa, Diamaden, and Bogert).

Protecting consumers and public health is possible if bottled water consumed as drinking water conforms to the limits for biological, physical, and chemical characteristics set by the EU and WHO. In order to protect customers, the primary ion and heavy metal analyses of bottled water sources must be carried out together and the same types of parameters must be analysed for the evaluation to be reliable.

The bottled waters from Turkey and certain other countries can be standardised if periodical chemical analysis can be enforced for all bottled water consumed in Turkey, because this will ensure that natural spring water and mineral water sold on domestic and international markets will protect the customer, will not pose a risk to public health and will conform to regulations issued by the World Health Organisation (WHO) and the European Community (EC).

\section{REFERENCES}

Al-Salehu, I., and Al-Doush, I., 1998, Survey of trace elements in household and bottled drinking water samples collected in Riyadh, Saudi Arabia, The Science of the Total Environment, v. 216, pp. 181-192.

Protecting the Consumer, 2003, Consumer protection law of Turkey. Ministry of Industry and Commerce, 4822: v. 13, Ankara

EPA (United States Environmental Protection Agency), 2001, National primary drinking water standards. Office of Water, EPA 816-F-01-007, 4 p., USA
Feru, A., 2004, Bottled natural mineral waters in Romania. Environmental Geology, v. 46(5), pp. 670-674

http://www.römerquelle.at (Römerquelle, Austria) http://www.pioule.com (Pioule, France)

http://www.buxtonwater.net (Buxton, England)

http://www.aguasierracazorla.com (Sierra Cazorla, Spain)

http://www.acquasanpellegrino.it (San Pellegrino, Italy)

http://www.mineralwaters.org (Vivien, Hungary)

http://www.mineralwaters.org (Dea, Poland)

http://www. mineralwaters.org (Korpi, Greece)

http://www.gerolsteiner.de (Gerolsteiner, Germany)

M. van der Aa., 2003, Classification of mineral water types and comparison with drinking water standards. Environmental Geology, v. 44, pp. 554-563

Nkono, N. A. and Asubiojo, O. I., 1997, Trace elements in bottled and soft drinks in Nigeria-a preliminary study. The Science of the Total Environment, v. 208: pp.161-163

Pehlivan, R. ve Yilmaz O., 1995, Marmara Bolgesi termomineral kaynaklarinin icilebilirligi ve insan sagligina etkisi. Jeoloji Muhendisligi Dergisi. v. 47, pp. 21-27, Ankara

Pehlivan, R., 1996, Termomineral su kaynaklar1 sifa da1t1r mi? Tubitak Bilim ve Teknik Dergisi 29, v. 343 pp. 96-98, Ankara

Pehlivan, R., Yilmaz, O., 2005, Water quality and hydrogeochemical characteristics of the Buyukmelen River, Duzce, Turkey. Hydrological Processes, v. 19(20), pp. 3947-3971, UK.

Reimann, C., Bjorvatn, K., Frengstad, B., Melaku ,Z., Haimanot, R. T., and Siewers, U., 2003, Drinking water quality in the Ethiopian section of the East African rift valley I-data and health aspects. The Science of the Total Environment, v. 311, pp. $65-80$.

Regulation, 1997, Turk gida kodeksi yonetmeligi, RG 23172 : 24, Ankara

Regulation, 2001, Icilebilir nitelikteki sular1n istihsali, ambalajlanmas1, satisi ve denetlenmesi hakk1nda yonetmelik, RG 24473, v. 17, Ankara

Regulation, 2003, Etiket, tarife ve fiyat listeleri yönetmeligi, RG 25137, v. 5, Ankara

Regulation, 2004, Dogal mineralli sular hakkinda yonetmelik, RG 25657, v. 18, Ankara

Turkish Standard, 1991, Maden suyu-icilebilir, TS 9130: v. 13, Ankara

Turkish Standard, 1997, Sular - icme ve kullanma sulari, TS 266: v. 32, Ankara

WHO, 1993, Guidelines for drinking-water quality recommendations. World Health Organization, $2^{\text {nd }}$ Edition., v. 1,188 p., Geneva 